\title{
AMPICILLIN SULBACTAM AND CEFOTAXIME ARE SIMILARLY EFFECTIVE IN PEDIATRIC PNEUMONIA
}

\author{
Diny Puspitasari, Didik Hasmono, Taufiqur Rahman \\ Faculty of Pharmacy, Universitas Airlangga, Surabaya
}

\begin{abstract}
ABSTRAK
Pneumonia merupakan infeksi yang terjadi paru-paru dan masih menyebabkan angka kematian yang tinggi pada balita saat ini. Penyebab utama adalah bakteri atau virus. Pemberian antibiotika tetap disarankan walaupun sulit mengetahui penyebabnya apakah bakteri atau virus. Ampisilin menjadi pilihan pertama beberapa guideline. Peningkatan resistensi di seluruh dunia menjadi salah satunya kekhawatiran akan efektivitas antibiotik. Terapi utama pneumonia balita di Rumah Sakit Muhammadiyah Lamongan adalah ampisilin sulbaktam dan sefotaksim. Penelitian dilakukan untuk menganalisa efektivitas keduanya. Penelitian ini bertujuan menganalisis perbedaan penggunaan ampisilin sulbaktam dan sefotaksim pada pasien pneumonia usia 3-59 bulan sejak November 2013-Maret 2014. Pasien yang memenuhi kriteria inklusi, yaitu pasien pneumonia sesuai kriteria WHO, secara prospektif dilakukan pengamatan terhadap data klinis,data laboratorium, data mikrobiologi. Setelah itu dianalisa mengetahui perbedaan efektifitas antara kedua antibiotika. Pada penelitian ini sebanyak 29 pasien masuk dalam kriteria inklusi, 17 pasien yang mendapat antibiotika ampisilin sulbaktam dan 12 pasien yang mendapat sefotaksim. Pada perbandingan rerata nadi diketahui terdapat penurunan bermakna nadi pasien kedua kelompok di hari kedua dan tidak terdapat perbedaan bermakna antara kedua kelompok ( $p=0,084)$. Demikian juga perbandingan rerata suhu $(p=0,117)$, laju nafas $(p=0,839)$, leukosit pasien $(p=0,429)$. Lama rawat inap untuk kelompok ampisilin sulbaktam 4,77 hari dan untuk kelompok sefotaksim 5,17 hari. Analisa menunjukkan tidak ada perbedaan antara lama rawat inap kedua kelompok $(p=0,275)$. Dari 22 pasien yang diambil sampelnya untuk pemeriksaan kultur darah hanya 1 pasien dengan hasil positif. Berdasarkan hasil penelitian tersebut dapat disimpulkan bahwa ampisilin sulbaktam dan sefotaksim efektif pada kasus pneumonia anak dan tidak ada perbedaan berdasarkan parameter suhu tubuh, laju nafas, nadi, leukosit dan lama rawat inap pasien. Regimentasi dosis sesuai guideline dan lama rawat inap kurang dari 10 hari. Tidak ditemukan efek samping kedua obat. (FMI 2016;52:116-121)
\end{abstract}

Kata kunci: efektivitas obat, pneumonia, antibiotika, ampisilin, sulbaktam, sefotaksim

\begin{abstract}
Pneumonia is an infection of the lungs that occurs and still cause high mortality in young children today. The main cause is bacterial or viral. Antibiotics still recommended though it is difficult to know the cause is bacterial or viral. Ampicillin be the first option some guideline. Increased resistance worldwide become one of them concerns the effectiveness of antibiotics. The main treatment of toddler pneumonia in Muhammadiyah Hospital Lamongan are ampicillin sulbactam and cefotaxime. The study was conducted to analyze the effectiveness of both antibiotics. This study aims to analyze comparison in the use of ampicillin sulbactam and cefotaxime pneumonia patients aged 3-59 months from November 2013 to March 2014. Patients who met the inclusion criteria were prospectively observed for clinical data, laboratory data, the data microbiology. After it is analyzed to know the difference between the effectiveness of antibiotics. In this study of 29 patients included in the inclusion criteria, 17 patients who received antibiotics ampicillin sulbactam and 12 patients receiving cefotaxime. In the comparison of the mean pulse pulse is known there is a significant reduction in both groups of patients on the second day and was not significantly different between the two groups ( $p=0.084)$. Likewise, the average ratio of temperature $(p=0.117)$, breath rate $(p=0.839)$, leukocytes of patients $(p=0.429)$. Length of stay for ampicillin sulbactam group was 4.77 days and 5.17 days for cefotaxime group. Analysis showed no differences between the two groups for lenght $(p=0.275)$. Of the 22 patients who were sampled for blood culture examination only 1 patient with positive results. Based on these results we can conclude that ampicillin sulbactam and cefotaxime effective in cases of children pneumonia, and there is no distinction based on the parameters in body temperature, breath rate, pulse, leukocytes and long hospitalization of patients. Regimentation dosage is appropriate based on guidelines, and length of stay less than 10 days. Found no side effects of both drugs. (FMI 2016;52:116-121)
\end{abstract}

Keywords: drug effectiveness, pneumonia, antibiotics, ampicillin, sulbactam, cefotaxime

Correspondence: Diny Puspitasari, Faculty of Pharmacy, Universitas Airlangga, Jalan Dharmawangsa Dalam, Surabaya 60286, Indonesia. 


\section{INTRODUCTION}

Respiratory tract infections diseases, especially pneumonia which occurs in under five years of age is a major cause of death in the world. The first five-year period is a period that is very sensitive to the environment so prone to malnutrition and diseases (WHO 2010). In 2004, pneumonia is the leading cause of death that is $>3$ million children under 5 years of which occurs in 1 out of 5 patients with pneumonia of children and occurred about 158 million cases of pneumonia each year (Bradley \& McCraken 2008, Sandora \& Sectish 2011). It is estimated that each year 150 million cases of pneumonia occur in developing countries where $95 \%$ of them are new cases. Indonesia ranks sixth of the total number of patients with pneumonia (Dalimunthe et al 2013).

Several interventions have been made to reduce global mortality due to pneumonia. Appropriate antibiotic treatment as soon as possible is an effective intervention to reduce mortality due to pneumonia. It is shown from a study in which treatment of pneumonia that quickly and precisely known more quickly fix common symptoms of pneumonia such as fever and rapid breathing or Tachypnoea (Hazir et al 2013).

Increased resistance to the bacteria that cause respiratory tract infections is a problem throughout the world, especially the bacterium Streptococcus pneumoniae resistance to penicillin and other antibiotics variety. Reported 51\% of isolates of Streptococcus pneumoniae to penicillin non susceptible, even in some Asian countries could reach $40-70 \%$. Research in Bali showed discharge as the most common cause of pneumonia and a high resistance to cefotaxime is $71.8 \%$. The important factor of increased resistance is excessive use of antibiotics and to suppress this election empiric antibiotics should pay attention to the pre-valence of the bacteria that cause at various age levels, resistance patterns germs local and immunization status of children (Harris et al 2011, Inoue et al 2005).

Proper management of the elections and the administration of antibiotics is one of the major management pneumonia case management. Sulbactam ampicillin and cefotaxime has been used as the main empirical therapy in cases of pneumonia of children in RS Muhammadiyah Lamongan (Data Installation Pharmacy RSML). With the lack of data regarding the effectiveness of the use of antibiotics in pneumonia cases, there is no map of germs and the difficulty of determining the etiology of pneumonia it is necessary to investigate the efficacy and safety differences ampicillin sulbactam compared cefotaxime in pediatric patients aged 3-59 months were included in the standard therapy for pneumonia RS Muhammadiyah Lamongan.

\section{MATERIALS AND METHODS}

This research is an analytic observational trials conducted prospectively. The subjects of this study were patients who were clinically and radiologically diagnosed as pneumonia and has fulfilled the inclusion and exclusion criteria of the study. Inclusion criteria were patients experienced severe pneumonia at the age of 359 months. Patients are very severe pneumonia (hard drinking, heavy breathing distress, cyanosis). Exclusion criteria were patients with complications (empyema, respiratory failure, malignancies, hematologic abnormalities) and congenital abnormalities (congenital heart disease). The sampling technique in this study using consecutive sampling which is a sampling technique to retrieve all existing subjects and meets the criteria according to research by a certain time until the desired sample size is met. The number of patients is all pneumonia patients who met the inclusion criteria in the period November 2013- March 2014.

Antibiotics are given within a maximum of 24 hours after the patients included in the study: Ampicillin sulbactam intravenously administered at a dose of 75$100 \mathrm{mg} / \mathrm{kg} /$ day divided into 3x Award and cefotaxime dengandosis $75-100 \mathrm{mg} / \mathrm{kg}$ /day divided into 3x Award. The duration of intravenous antibiotic therapy for at least 3 days. The data required to observe the therapeutic response was clinical data such as body temperature, Respiratory Rate, their retractions, nasal flaring, cyanosis, grunting and data radiological breath. Observations response to antibiotic therapy was measured on the first day to five patients were treated in hospital and before leaving the hospital. Observation of the side effects do after drug administration by observing the clinical signs and patient complaints.

Data from a data collection sheet is processed and analyzed. A descriptive analysis of the characteristics of the study subjects as well as the comparison of characteristics between the two groups, namely the empiric antibiotic therapy sulbactam ampicillin and cefotaxime. Klomogorov Smirnov test or Shapiro Wilk normality test data. $\mathrm{T}$ test or Wilcoxon paired samples to test the differences between the parameters of temperature, pulse, RR, leukocyte concentration between before administration and after administration of antibiotics. 


\section{RESULTS}

Samples that meet the inclusion criteria were 29 patients ie 17 patients treated with ampicillin sulbactam and 12 patients receiving cefotaxime. All patients were followed is a diagnosis of pneumonia and bronchopneumonia patients without congenital disease or other chronic illnesses and have never been admitted 14 days in advance. All the patients had not received the vaccine for Streptococcus pneumoniae and Haemophyllus influenzae, other than that obtained tuberculin test results were negative in some patients with suspected TB. Differences in characteristics between the two groups can be seen in Table 1 .

On examination of early clinical symptoms found some common symptoms such as cough, fever, shortness and others. Clinical symptoms of the two groups can be seen in the table below, which can be seen coughing experienced by all patients. At the time of admission all patients received empirical intravenous antibiotics until at discharge. Good old empiric antibiotics ampicillin and cefotaxime sulbactam at least 3 days and most $(50 \%)$ for 5 days All intravenous antibiotics given from the first day of admission and a maximum of 2 hours after the diagnosis of pneumonia. Dosage and duration of antibiotic treatment of two groups can be seen in Table 2 .

At the last known infection parameter changes between before and after is mostly in the normal state after administration, except for cough. All patients in a state of reduced cough on admission. While crowded, retractions, dyspnea, respiratory nostril was not experienced by all patients on admission.

The patient's pulse is the average pulse on measurement in the morning. In the picture below looks significant decrease pulse on the second day were treated in hospital and between the two groups is not too visible difference from the first to the fifth day of treatment. Statistical analysis showed the average pulse at the beginning of the admission between groups sulbactam ampicillin and cefotaxime group known no significant difference $(p=0.721)$. Similar results were obtained after administration of ampicillin and sulbactam is no difference in the average pulse after the second administration of antibiotics before discharge $(p=0.084)$. From the comparison of the pulse at the beginning of admission and before discharge in each group known to have a significant decrease in pulse.

The patient's body temperature is the average temperature measurements in the morning. In the picture below looks significantly decrease the average temperature on the second day of observation RS.Dari treated in the average temperature of patients at baseline and before discharge seemed to decline, especially in the second day of observation. Statistical analysis shows the initial temperature comparison admission does not appear differences between groups sulbactam ampicillin and cefotaxime. In observation of the average temperature after administration of sulbactam ampicillin and cefotaxime before discharge showed no significant difference between the two $(p=0.177)$. While the ratio of the average temperature at the beginning of admission and before discharge in each group discovered that the average pulse decreased significantly $(p<0.05)$.

Table 1. Differences in characteristics between groups sulbactam ampicillin and cefotaxime by age, sex and weight

\begin{tabular}{cccc}
\hline Characteristics & $\begin{array}{c}\text { Ampicillin/ } \\
\text { Sulbactam } \\
\text { Group }\end{array}$ & $\begin{array}{c}\text { Cefotaxim } \\
\text { Group }\end{array}$ & p values \\
\hline $\begin{array}{c}\text { Age } \\
\text { Age in months } \\
\text { (median,range) }\end{array}$ & $12(5-36)$ & $12(9-59)$ & $0,299^{\mathrm{a}}$ \\
$\begin{array}{c}\text { Sex } \\
\text { Male }\end{array}$ & $77 \%$ & $69 \%$ & $0,158^{\mathrm{b}}$ \\
$\begin{array}{l}\text { Body weight } \\
\text { (median kg, range) }\end{array}$ & $9(5-15)$ & $8,5(6-19)$ & $0,078^{\mathrm{c}}$ \\
\hline
\end{tabular}

Notes $*=$ percentage is calculated based on the total number of patients that 29 patients

$\mathrm{a}=$ using Mann Whitney

$\mathrm{b}=$ chi square test

$\mathrm{c}=$ using unpaired $\mathrm{t}$ test

Table 2. The dose and duration of use of antibiotics ampicillin and cefotaxime sulbactam pneumonia patients Kids IRNA RSML the period November 2013 - March 2014

\begin{tabular}{lcccc}
\hline $\begin{array}{c}\text { Types of } \\
\text { antibiotics }\end{array}$ & Route & $\begin{array}{c}\text { Doses applied } \\
(\mathrm{mg} / \mathrm{kg} / 24 \mathrm{~h})\end{array}$ & $\begin{array}{c}\text { Number of } \\
\text { patients* }\end{array}$ & $\begin{array}{c}\text { Duration of } \\
\text { administration }\end{array}$ \\
\hline Ampicillin & iv & $75-100(3 \times 1)$ & 17 & $3-5$ days \\
$\begin{array}{l}\text { Sulbactam } \\
\text { Cefotaxime }\end{array}$ & Iv & $75-100(3 \times 1)$ & 12 & $4-7$ days \\
\hline
\end{tabular}


Table 3. Parameters of infection and clinical symptoms of infant pneumonia patients before and after antibiotic therapy

\begin{tabular}{|c|c|c|c|c|}
\hline \multirow[t]{2}{*}{ Parameter } & \multicolumn{2}{|c|}{$\begin{array}{c}\text { Ampicillin } \\
\text { Sulbactam }(n=17)\end{array}$} & \multicolumn{2}{|c|}{$\begin{array}{c}\text { Cefotaxime } \\
(\mathrm{n}=12)\end{array}$} \\
\hline & Before & After & Before & After \\
\hline \multicolumn{5}{|l|}{ Temperature } \\
\hline Normal & 5 & 16 & 4 & 11 \\
\hline Increased & 12 & 1 & 8 & 1 \\
\hline \multicolumn{5}{|l|}{ Pulse } \\
\hline Normal & 13 & 16 & 9 & 11 \\
\hline Increased & 4 & 1 & 3 & 1 \\
\hline \multicolumn{5}{|l|}{$\mathrm{RR}$} \\
\hline Normal & 7 & 17 & 6 & 12 \\
\hline Increased & 10 & 0 & 6 & 0 \\
\hline \multicolumn{5}{|l|}{ Retraction } \\
\hline Normal (no retraction) & 8 & 17 & 7 & 12 \\
\hline Present & 9 & 0 & 5 & 0 \\
\hline \multicolumn{5}{|l|}{ Nostril breathing } \\
\hline Normal (not present) & 11 & 17 & 9 & 12 \\
\hline Present & 6 & 0 & 3 & 0 \\
\hline \multicolumn{5}{|l|}{ Cough } \\
\hline Normal (no cough) & 0 & 0 & 0 & 0 \\
\hline Present & 17 & 17 & 17 & 17 \\
\hline \multicolumn{5}{|l|}{ Asphyxia } \\
\hline Normal (not present) & 9 & 17 & 4 & 12 \\
\hline Present & 8 & 0 & 8 & 0 \\
\hline \multicolumn{5}{|l|}{ Dyspnea } \\
\hline Normal (no dyspnea) & 4 & 17 & 4 & 12 \\
\hline Present & 13 & 0 & 8 & 0 \\
\hline \multicolumn{5}{|l|}{ Leukocytes } \\
\hline Normal & 12 & 14 & 8 & 7 \\
\hline Abnormal & 5 & 0 & 4 & 2 \\
\hline
\end{tabular}

From the observation of the average rate of the patient's airway at the outset and before discharge seemed to decline, especially in the second day of observation. The statistical analysis shows a comparison of the rate of breathing during initial admission does not appear differences between groups sulbactam ampicillin and cefotaxime. In observation of the average rate of breaths after administration of sulbactam ampicillin and cefotaxime before discharge showed no significant difference between the two $(p=0.839)$. While the ratio of the rate of breathing during initial admission and before discharge in each group discovered that the average pulse decreased significantly $(\mathrm{p}<0.05)$.
From table 2 unknown at the beginning of leukocytes comparison admission does not appear differences between groups sulbactam ampicillin and cefotaxime. In observation of leukocytes after administration of sulbactam ampicillin and cefotaxime before discharge showed no significant difference between the two $(p=$ 0.710 ). While the ratio of leukocytes at the beginning of admission and before discharge in each group is known to have a significant decrease $(\mathrm{p}<0.05)$. Old infant hospitalized pneumonia patients at Children IRNA RSML the period November 2013 - March 2014 that the research samples can be seen in Table 5 .

Table 4. Observation leukocytes of patients at the beginning of admission and before discharge group sulbactam ampicillin and cefotaxime

\begin{tabular}{|c|c|c|c|}
\hline Antibiotic groups & $\begin{array}{c}\text { Leukocyte } \\
\text { on admission }\end{array}$ & $\begin{array}{l}\text { Leukocytes before } \\
\text { admission }\end{array}$ & $\mathrm{p}$ \\
\hline $\begin{array}{l}\text { Ampicillin- } \\
\text { sulbactam }\end{array}$ & $4.7-28.8$ & $5.9-11.5 \quad(n=6)$ & $0.036^{* *}$ \\
\hline Cefotaxime & $5.9-21.7$ & $6.2-14.4 \quad(n=7)$ & $0.018 * *$ \\
\hline & $\mathrm{P}: 0.970^{*}$ & $\mathrm{P}=0.429^{*}$ & \\
\hline
\end{tabular}


Table 5. Profile longer inpatient pneumonia patients

\begin{tabular}{lcc}
\hline Antibiotic groups & $\begin{array}{c}\text { Mean } \\
\text { Hospitalization } \\
\text { Days }( \pm \text { SD) }\end{array}$ & $\mathrm{p}$ \\
\hline Ampicillin-sulbactam & $4.77 \pm 0.75$ & $0.275^{*}$ \\
Cefotaxime & $5.17 \pm 1.19$ & \\
\hline Notes: ${ }^{*}=$ unpaired t test & &
\end{tabular}

From the table a long profile of hospitalization between the two groups is almost the same and there was no significant difference between the two groups is approximately 5 days $(\mathrm{p}>0.05)$.

From the examination of only one patient is an $\mathrm{RH}$ with a positive culture results. Antibiotics given that cefotaxime is not included in the study so it is not known whether it is appropriate to address the bacteria found that A. Staphylococcus sp.

\section{DISCUSSION}

The research showed 29 patients with a diagnosis of pneumonia that 17 patients from ampicillin sulbactam group and 12 patients who obtain cefotaxime. From table 5.1 in mind the majority of patients gender to male patients - men, accounting for 22 patients $(76 \%)$ and female patients by 7 patients $(2 \%)$. Here appears the number of male patients more than female patients between groups sulbactam ampicillin and cefotaxime. The nutritional status of patients also is one of the risk factors that may affect the condition suffered pneumonia. Based on research data shown in Table 2 is known that most patients have good nutrition with 26 patients (90\%) and the remaining 3 patients with malnutrition. Patients with malnutrition become more susceptible to infections, even mild malnutrition can affect the immune system either cell mediated or antibody (Schaible and Kaufmann 2007).

The study found the number of patients with pneumonia age infants less than age 1-5 yrs where this can be caused by exclusive breastfeeding, improving nutritional status and sampling at regular intervals. Breast milk is the ideal nutrition for growth and development of babies, other than that it contains antibacterial and antiviral ingredients as autoimmune (Katona \& KatonaApte 2008). On a table comparing the different characteristics based on age, gender and weight using statistical analysis among patients receiving ampicillin sulbactam and pneumonia showed no difference between the two groups. Table 3 shows the results of the clinical symptoms experienced by patients with pneumonia baby. Some common clinical symptoms the same as other studies such as cough, shortness of breath, crackles, retractions, dyspnea, and fever. Clinical symptoms of the majority in this study were cough and crackles experienced by 29 patients (100\%) and 27 patients (93\%) respectively - participated. After the fever, dyspnea, tightness, tachypnea. Tachypnea which has been reported as the most sensitive sign of pneumonia (Harris et al 2011).

Sulbactam ampicillin and cefotaxime dose given in the table can be seen between the range of 75-100 $\mathrm{mg} / \mathrm{kg}$ where this is in accordance with the guidelines given WHO (WHO 2005). Some other guidelines indicate Award may be increased to $200 \mathrm{mg} / \mathrm{kg}$. Old antibiotic therapy in this study is approximately 4-5 days followed by oral administration for about 3 days. WHO said antibiotics in total about 5 days (WHO 2005). A study by shortening the duration of antibiotics beta lactam intravenous pneumonia patients into 4 days demonstrated the safety and effectiveness of same by administration for 7 days. Shortening the duration will lower maintenance costs, lower the risk of nosocomial infection and other side effects (Peltola et al 2001).

From the statistical analysis is known to be significantly different between temperature, breath rate, pulse in a patient group sulbactam ampicillin and cefotaxime. Addition of inpatient comparison of old and leukocyte profile before discharge showed no difference in the use of antibiotics ampicillin and cefotaxime sulbactam in cases of child pneumonia. In terms of the patient's clinical condition both signs of infection and length of stay did not reveal any significant difference between patients receiving ampicillin/sulbactam and cefotaxime so cefotaxime as broad-spectrum antibiotics are no better than ampicillin sulbactam which included a narrow spectrum of antibiotics. This support by the IDSA guidelines recommending the use of penicillins are ampicillin for child pneumonia patients in the hospital.

\section{CONCLUSION}

The use of antibiotics infant pneumonia patients stated that there were no good treatment failure among patients treated with empiric antibiotics ampicillin and cefotaxime sulbactam iv iv and long hospitalization of patients between 3-7 days, the regimentation of ampicillin sulbactam dose (75-100 $\mathrm{mg} / \mathrm{kg}$ ) and cefotaxime (75$100 \mathrm{mg} / \mathrm{kg}$ ) in accordance with the guidelines and the duration of intravenous antibiotics in under 10 days, and there was no difference in the effectiveness of the administration of the two views of the parameter value leukocytes, body temperature, pulse rate, breath rate and duration of hospitalization. 


\section{REFERENCES}

Bradley JS and McCracken GH (2008). Unique considerations in the evaluation of antibacterials in clinical trials for pediatric community-acquired pneumonia. Clinical Infectious Disease 47, S241-S247

Dalimunthe W, Daulay RS, Daulay RM (2013). Significant clinical features in pediatric pneumonia. Paediatrica Indonesiana 53, 37-40

Harris M, Clark J, Coote N, Flether P, Harnden A, McKean M, Thomson A, On behalf of the British Thoracic Society Standards of Care Committee (2011). British thoracic society guidelines for the management of community acquired pneumonia in children: update 2011. Thorax 66, ii23

Hazir T, Begum K, el Arifeen S, Khan AM, Huque MH, Kazmi N, Roy S, Abbasi S, Rahman QS, Theodoratou E, Khorshed MS, Rahman KM, Bari S, Kaiser MMI, Saha SK, Ahmed ASMNU, Rudan I, Bryce J, Qazi SA, Campbell H (2013). Measuring coverage in $\mathrm{MNCH}$ : a prospective validation study in Pakistan and Bangladesh on measuring correct treatment of childhood pneumonia. PLoS Med 10, e1001422

Inoue $\mathrm{M}$, Kohno $\mathrm{S}$, Kaku M, Yamaguchi $\mathrm{K}$, Igari J, Yamanaka K (2005). PROTEKT 1999-2000: a multicentre study of the antimicrobial susceptibility of respiratory tract pathogens in Japan. International Journal of Infectious Diseases 9, 27-36

Katona P and Katona-Apte J (2008). The interaction between nutrition and infection. Clinical Infectious Diseases 46, 1582-1588

Peltola H, Vuori-Holopainen E, Kallio MJT, The SETU Study Group (2001). Successful shortening from seven to four days of parenteral beta-lactam treatment for common childhood infections: a prospective and randomized study. International Journal of Infectious Diseases 5, 3-8

Sandora TJ and Sectish TC (2011). Community acquired pneumonia. In: Kliegman RM, Stanton BMD, St Geme J, Schor NF, Behrman RE (eds). Nelson Textbook of Pediatrics, 19th ed, Philadelphia, Saunders, chapter 392

Schaible UE and Kaufmann SHE (2007). Malnutrition and infection: complex mechanisms and global impacts. PLoS Med 4, e115

WHO (2010). Revised WHO classification and treatment of schilhood penumonia at health facilities. Availbale from http://apps.who.int/iris/bitstream/ 10665/137319/1/9789241507813_eng.pdf. Accessed Oktober 2, 2014 